\title{
Elaboration and Evaluation of Typical Puerto Rican Dishes Prepared with Mixtures of Plantain, Cassava and Tanier Flours ${ }^{1}$
}

\author{
Isabel B. de Caloni and José R. Cruz-Cay²
}

\begin{abstract}
Mixtures of flours from plantain (Musa acuminata $\times$ balbisiana AAB), cassava (Manihot esculenta Crantz) and tanier (Xanthosoma spp) were prepared for the elaboration of typical Puerto Rican dishes. The proportion of flours blended were the following-50:25:25, 60:20:20, 75:15:10 and 75:10:15 of plantain, cassava, and tanier, respectively. Plantain flour was always used as the main flour because of the commercial importance of this crop on the Island. The blends were prepared with $454 \mathrm{~g}$ of combined flours mixed with $1250 \mathrm{~g}$ boiling water, $11.5 \mathrm{~g}$ of salt and $36.0 \mathrm{~g}$ of annatto seed in oil (achiote). "Pasteles" and "alcapurrias" (a boiled meat pie and turnovers, respectively), were prepared and found acceptable by a trained taste panel. No significant difference in general acceptability was observed among the samples prepared with the mixtures of flours when fresh and after 3 months frozen storage.
\end{abstract}

\section{INTRODUCTION}

Plantain (Musa acuminata $\times$ balbisiana AAB), cassava (Manihot esculenta Crantz) and tanier (Xanthosoma spp) are starchy crops commonly used in tropical countries such as Puerto Rico. Plantain production ranks third in importance among all food crops (3). González Villafañe (4) concluded that as a result of the adoption of modern technology recommended by the Agricultural Experiment Station farmers can increase their yields greatly. To deal with problems of overproduction during the summer, it is necessary to process new products from plantains.

The Food Technology Laboratory of the Agricultural Experiment Station has conducted several studies to develop new products from plantain. With this objective, Cancel et al. (2) developed a method for the commercial processing of plantain chips, Sánchez and Hernández worked out procedures for the preparation of frozen ripe plaintains in syrup (11), and Caloni (1) developed a method for preparing "mofongo," a native dish, from mashed green plantains that when frozen keeps well for 7 months. Sánchez et al. conducted several studies on the freezing of green plantains, raw and pre-fried slices (tostones) $(12,13,14,15)$, and Rahman (8) developed an economical method for producing flour of acceptable quality from green plantains.

Cassava does not store well as a fresh vegetable; and spoils a few days after harvest. Although the production of this starchy crop in Puerto

\footnotetext{
${ }^{1}$ Manuscript submitted to Editorial Board December 8, 1982.

${ }^{2}$ Associate Food Technologist, Food Technology Laboratory, Agricultural Experiment Station, Mayagúez Campus, University of Puerto Rico, Rio Piedras, P.R.
} 
Rico is not as high as that of plantain, economical ways to store cassava as a processed product are needed. González-Padin (5) concluded that it is feasible to prepare several dishes (purée, crab meat-stuffed pie and sweet pudding) from instant cassava flakes stored for 12 weeks. The dishes prepared were well accepted by a tasting panel. Recently, Rodriguez-Sosa et al. (10) studied the pasting properties of plantain, cassava and tanier flours and various mixtures prepared from them.

Tanier can be stored at ambient conditions for only a few weeks, but as with plantain, methods are needed for storing tanier for extended periods. Rodriguez and González developed a method for the preparation of flakes as a means of preserving tanier (9). Sánchez and Parsi (16) and Sánchez and Caloni (17) worked out procedures to freeze tanier to be used in the preparation of vario as dishes.

Starchy vegetables such as plantain, cassava and tanier provide the daily diet mostly with complex carbohydrates, some vitamins and minerals. Usually, they are boiled or otherwise prepared in some dish that combines them with meat or cheese. Two of the most popular typical dishes in Puerto Rico are "pasteles" (prepared from a mixture of grated green plantain, tanier and stuffed with stewed cubed meat, then wrapped in plantain leaves and boiled in salted water until cooked), and "alcapurrias" (prepared from grated plantain and tanier or grated cassava, stuffed with stewed ground meat and fried). The peeling and grinding of plantain, tanier and cassava is a tedious, time consuming job. Flours industrially prepared from these crops can simplify the preparation of many dishes.

This study was conducted to establish the utilization of blends from plantain, cassava and tanier flours in the preparation of pasteles and alcapurrias and to determine the acceptability.

\section{MATERIALS AND METHODS}

We peeled the plantains after soaking then in hot water at $210^{\circ} \mathrm{F}\left(98.9^{\circ}\right.$ C) for 5 minutes. They were hand peeled, cut in $1 / 4$ in cubes in a cutting machine and soaked in a $1,000 \mathrm{p} / \mathrm{m}$ potassium bisulfate solution for 3 $\min (13)$.

Taniers were peeled by the method of Sánchez-Nieva and Hernández (18), which consists of dipping the taniers in a $15 \%$ lye solution at $93^{\circ} \mathrm{C}$ for $6.5 \mathrm{~min}$. The peeled taniers were dipped in a $5 \%$ citric acid solution, trimmed and then dipped for $5 \mathrm{~min}$ in a $1 \%$ potassium metabisulfite solution at $\mathrm{pH} 3.0(19)$.

Cassava was hand peeled, and no treatment was used.

Flours were prepared following Rahman's method (8), which briefly consists of placing the samples in perforated trays of $30 \times 20 \times 2$ in to a depth to cover the whole area of the tray. Trays were placed in a cabinet 
TABLE 1.-Quality of "pasteles" prepared with mixtures of plantain, cassava and tanier flours when fresh and after 3 months

\begin{tabular}{|c|c|c|c|c|c|c|c|c|c|}
\hline \multirow{2}{*}{$\begin{array}{l}\text { Mixtures of plantain, cassava } \\
\text { and tanier flours }\end{array}$} & \multirow{2}{*}{$\begin{array}{l}\text { Days in } \\
\text { Storage }\end{array}$} & \multicolumn{2}{|c|}{ Appearance } & \multicolumn{2}{|c|}{ Flavor } & \multicolumn{2}{|c|}{ Texture } & \multicolumn{2}{|c|}{$\begin{array}{c}\text { General } \\
\text { acceptability }\end{array}$} \\
\hline & & Score $^{1}$ & Rating & Score & Rating & Score & Rating & Score & Rating \\
\hline \multirow[t]{3}{*}{$50 \%: 25 \%: 25 \%$} & Fresh & 5.42 & Like & 5.13 & Like & 4.92 & Like & 5.00 & Like \\
\hline & 90 & 5.40 & Like & 4.02 & Like & 4.92 & Like & 4.20 & Like \\
\hline & & & & & Moderately & & & & Moderately \\
\hline \multirow[t]{2}{*}{$60 \%: 20 \%: 20 \%$} & Fresh & 5.43 & Like & 5.71 & Like & 5.29 & Like & 5.29 & Like \\
\hline & 90 & 5.40 & Like & 5.40 & Like & 5.30 & Like & 5.40 & Like \\
\hline \multirow[t]{3}{*}{$75 \%: 15 \%: 10 \%$} & Fresh & 5.00 & Like & 4.45 & Like & 4.32 & Like & 4.51 & Like \\
\hline & & & & & Moderately & & Moderately & & Moderately \\
\hline & 90 & 5.13 & Like & 4.82 & Like & 4.75 & Like & 4.50 & Like \\
\hline \multirow[t]{3}{*}{$75 \%: 10 \%: 15 \%$} & Fresh & 5.01 & Like & 4.90 & Like & 4.37 & Like & 5.00 & Like \\
\hline & & & & & & & Moderately & & \\
\hline & 90 & 5.50 & Like & 5.00 & Like & 5.10 & Like & 5.33 & Like \\
\hline
\end{tabular}

${ }^{1}$ Six-point scale; $6=$ Like very much; $5=$ Like; $4=$ Like moderately; $3=$ Neither like nor dislike; $2=$ Dislike a bit; $1=$ Dislike. 
dehydrator. The dry-bulb temperature was set at $200^{\circ} \mathrm{F}\left(93.3^{\circ} \mathrm{C}\right)$, and after 1 hour it was reduced to $160^{\circ} \mathrm{F}\left(71.1^{\circ} \mathrm{C}\right)$ for the remaining 5 hours of the dehydration period. The air draft was set at 0.1 in $(0.25 \mathrm{~cm})$. The wet bulb temperature varied from $110^{\circ} \mathrm{F}\left(43.3^{\circ} \mathrm{C}\right)$ to $130^{\circ} \mathrm{F}\left(54.4^{\circ} \mathrm{C}\right)$. The dehydrated cubes were ground in a mechanical grinder to a mesh of 0.33 in $(0.84 \mathrm{~cm})$. The flour was stored in polyethylene bags.

Blends of plantain, cassava and tanier flours were prepared with the plantain flour always as the main flour. The mixtures were as follows:

$\begin{array}{ccc}\text { Plantain } & \text { Cassava } & \text { Tanier } \\ \% & \% & \% \\ 50 & 25 & 25 \\ 60 & 20 & 20 \\ 75 & 15 & 10 \\ 75 & 10 & 15\end{array}$

TABLE 2,-Results of quality appraisal of "pasteles" using \pm 2 scale, when fresh and after 3 months storage

\begin{tabular}{cccc}
\hline $\begin{array}{c}\text { Mixtures of plantain, cassava } \\
\text { and tanier flours }\end{array}$ & $\begin{array}{c}\text { Days in } \\
\text { storage }\end{array}$ & Score $^{1}$ & Results \\
\hline $50 \% ; 25 \% ; 25 \%$ & Fresh & 0.65 & Acceptable \\
& 90 & 0.90 & Acceptable \\
$60 \% ; 20 \% ; 20 \%$ & Fresh & 1.25 & Acceptable \\
& 90 & 1.57 & Acceptable \\
$75 \% ; 15 \% ; 10 \%$ & Fresh & 0.50 & Acceptable \\
& 90 & 1.13 & Acceptable \\
$75 \% ; 10 \% ; 15 \%$ & Fresh & 1.15 & Acceptable \\
& 90 & 1.33 & Acceptable \\
\hline
\end{tabular}

${ }^{1}+2,-2$ Scale, where $+2=$ very acceptable; $+1=$ acceptable; $0=$ questionable $;-1=$ slightly unacceptable; $-2=$ not acceptable.

To prepare the doughs for the "pasteles" and "alcapurrias", we mixed $454 \mathrm{~g}$ of the blended flours with $11.5 \mathrm{~g}$ salt, $36 \mathrm{~g}$ annato seed in oil and 1,000 to $1,250 \mathrm{~g}$ boiling water. The dough was stirred well for 5 minutes and left covered at room temperature to rehydrate for 1 hour.

The "pasteles" were stuffed with stewed cubed pork and condiments. We shaped them by spreading $65 \mathrm{~g}$ of the dough on a plantain leaf and placing the $15 \mathrm{~g}$ of meat stew in the center, then folding the leaf in rectangular shape and wrapping with a string.

The "alcapurrias" were stuffed with ground beef stew and condiments. For each "alcapurria" we spread 65 g of the dough on special freezer paper, stuffed it with $15 \mathrm{~g}$ of the meat stew and shaped in rectangular form with the paper. 
TABLE 3.-Quality of "alcapurrias" prepared with mixtures of plantain, cassava, and tanier flours when fresh and after 3 months

\begin{tabular}{|c|c|c|c|c|c|c|c|c|c|}
\hline \multirow{2}{*}{$\begin{array}{l}\text { Mixtures of plantain, cassava } \\
\text { and tanier flours }\end{array}$} & \multirow{2}{*}{$\begin{array}{l}\text { Days in } \\
\text { storage }\end{array}$} & \multicolumn{2}{|c|}{ Appearance } & \multicolumn{2}{|c|}{ Flavor } & \multicolumn{2}{|c|}{ Texture } & \multicolumn{2}{|c|}{$\begin{array}{l}\text { General } \\
\text { acceptability }\end{array}$} \\
\hline & & Score $^{1}$ & Rating & Score & Rating & Score & Rating & Score & Rating \\
\hline \multirow[t]{2}{*}{$50 \% ; 25 \% ; 25 \%$} & Fresh & 4.90 & Like & 4.45 & $\begin{array}{l}\text { Like } \\
\text { Moderately }\end{array}$ & 4.27 & $\begin{array}{l}\text { Like } \\
\text { Moderately }\end{array}$ & 4.00 & $\begin{array}{l}\text { Like } \\
\text { Moderately }\end{array}$ \\
\hline & 90 & 5.00 & Like & 4.40 & $\begin{array}{l}\text { Like } \\
\text { Moderately }\end{array}$ & 4.60 & Like & 4.45 & $\begin{array}{l}\text { Like } \\
\text { Moderately }\end{array}$ \\
\hline \multirow[t]{2}{*}{$60 \% ; 20 \% ; 20 \%$} & Fresh & 5.09 & Like & 4.51 & Like & 5.01 & Like & 5.40 & Like \\
\hline & 90 & 5.40 & Like & 5.30 & Like & 5.40 & Like & 5.40 & Like \\
\hline \multirow[t]{2}{*}{$75 \% ; 15 \% ; 10 \%$} & Fresh & 5.00 & Like & 4.29 & $\begin{array}{l}\text { Like } \\
\text { Moderately }\end{array}$ & 4.51 & Like & 5.00 & Like \\
\hline & 90 & 5.00 & Like & 4.76 & Like & 4.71 & Like & 4.60 & Like \\
\hline \multirow[t]{2}{*}{$75 \% ; 10 \% ; 15 \%$} & Fresh & 4.29 & $\begin{array}{l}\text { Like } \\
\text { Moderately }\end{array}$ & 4.86 & Like & 4.71 & Like & 4.60 & Like \\
\hline & 90 & 4.75 & Like & 4.86 & Like & 4.86 & Like & 4.85 & Like \\
\hline
\end{tabular}

\footnotetext{
${ }^{1}$ Six-point scale.
} 
Both dishes were prepared by the methods recommended by Valldejuly (20), and were stored at $-23.3^{\circ} \mathrm{C}\left(-10^{\circ} \mathrm{F}\right)$.

For organoleptic tests, the "pasteles" were cooked without thawing, boiled in salted water for 30 minutes. The "alcapurrias" were fried without thawing in shortening at $176.6^{\circ} \mathrm{C}\left(350^{\circ} \mathrm{F}\right)$ for 12 minutes until cooked and golden brown.

The "pasteles" and "alcapurrias" were submitted to a trained taste panel for organoleptic evaluations based on a 6-point hedonic scale (7); and a second test for overall quality rating with a \pm 2 scale (6).

\section{RESULTS AND DISCUSSION}

Table 1 shows the results of organoleptic tests conducted with "pasteles" when fresh and after 3 months frozen storage. In general, the good

TABLE 4.-Results of quality appraisal of "alcapurrias" using \pm 2 scale when fresh and after 3 months storage

\begin{tabular}{cccc}
\hline $\begin{array}{c}\text { Mixtures of plantain cassava } \\
\text { and tanier flours }\end{array}$ & $\begin{array}{c}\text { Days in } \\
\text { storage }\end{array}$ & Score $^{1}$ & Results \\
\hline $50 \% ; 25 \% ; 25 \%$ & Fresh & 0.50 & Acceptable \\
& 90 & 1.01 & Acceptable \\
$60 \% ; 20 \% ; 20 \%$ & Fresh & 1.50 & Acceptable \\
& 90 & 1.88 & Acceptable \\
$75 \% ; 15 \% ; 10 \%$ & Fresh & 1.46 & Acceptable \\
& 90 & 1.50 & Acceptable \\
$75 \% ; 10 \% ; 15 \%$ & Fresh & 0.75 & Acceptable \\
& 90 & 1.00 & Acceptable \\
\hline
\end{tabular}

${ }^{1} \pm 2$ scale.

quality "pasteles" had good acceptability. This acceptability held for pasteles 3 months in frozen storage.

When the "pasteles" were submitted for evaluation with the \pm 2 scale, no significant difference was found among the samples prepared with the different mixtures. Since a rating of 0.50 and over in this type of test indicates that the sample has an acceptable quality, all samples prepared were found to be similarly acceptable. Table 2 shows the results of this test.

Tables 3 and 4 show the results of organoleptic evaluations of "alcapurrias." Samples prepared with the different mixtures of flours were rated between "like" and "like moderately" in appearance, flavor, texture, and overall acceptability. No significant difference was observed between the samples when evaluated for general quality when the \pm 2 scale for acceptability, was used. 


\section{RESUMEN}

Se estudió la viabilidad de elaborar "pasteles" y "alcapurrias", dos platos nativos, con mezclas de harina de plátano (Musa acuminata $\times$ balbisiana $A A B$ ), de yuca (Manihot esculenta) y de yautía (Xanthosoma spp.). Las mezclas de harinas se prepararon con porcentajes de 50-25-25, 60-20$20,75-15-10$ y $75-10-15$ en el mismo orden: plátano, yuca y yautía. Las masas para los pasteles y alcapurrias se prepararon con $454 \mathrm{~g}$ de las mezclas de harinas, $1,250 \mathrm{~g}$ de agua hirviendo, $11.5 \mathrm{~g}$ de sal y $36.0 \mathrm{~g}$ de achiote en aceite. Los pasteles se rellenaron con carne de cerdo picada en dados y guisada; las alcapurrias con carne de res molida guisada. En ambos casos se siguió el método comúnmente recomendado para prepararlos.

Los catadores apreciaron la calidad de los pasteles y alcapurrias por 3 meses a temperaturas de $-23.3^{\circ} \mathrm{C}$ y los juzgaron aceptables.

\section{LITERATURE CITED}

1. Caloni, I. B., 1982. Estación Experimental logra conservar el mofongo de plátano verde por congelación. Esta. Exp. Agric. Univ. P.R., Adelanto Científico 98.

2. Cancel, L. E., González, M. A. and Sánchez-Nieva, F., 1962. Elaboración del platanutre, Esta. Exp. Agric. Univ. P.R., Food Tech. Lab. Misc. Publ. 6.

3. Depto. Agricultura (1981), Ingreso Agricola de P.R. 1978/79-1979/80.

4. González-Villafañe, E., 1982. Economic impact of modern technology on plantain production, J. Agri. Univ. P.R. 66 (4): 250-53.

5. González-Padín, S., 1980. Aprovechamiento de la raíz de yuca. (Manihot esculenta Crantz) en la elaboración de hojuelas deshidratadas, Tesis MS Tecnologia de Alimentos, Universidad Iberoamericana, México, D.F.

6. Kramer, A. and Ditman, L. P., 1956. A simplified variable taste panel method for determining flavor changes in vegetables treated with pesticides, Food Technol. 10 (3): 155-59.

7. Peryam, D. R. and Pilgrim, F. J., 1957. Hedonic scale method for measuring food preference, Food Technol. 11 (9): 9-14.

8. Rahman, A. R., 1963. Economical method for the production of flour from green plantains, J. Agri. Univ. P.R. 47 (1): 1-10.

9. Rodríguez-Sosa, E. and González M. A. 1977. Preparation of instant tanier (Xanthosoma sagittifolium) flakes, J. Agri. Univ. P.R. 61 (1): 26-31.

10. Rodríguez-Sosa, E., Cruz-Cay, J. R. and Caloni, I. B., 1983. Amylography of plantain, cassava and tanier flour, J. Agri. Univ. P.R. 67 (3): 303-10.

11. Sánchez-Nieva, F. and Hernández, I., 1967. Preparación y conservación de plátanos manduros en almibar, Esta. Exp. Agric. Univ. P.R. Laboratorio de Technologie de Alimentos Food Tech. Lab. Publ. Misc. 7.

12. — - - and Bueso, C., 1975. Studies on the freezing of green plantains (Musa paradisiaca) I. Effect of blanching treatments on the quality and storage life of raw and pre-fried slices, J. Agric. Univ. P.R. 59 (2): 85-91.

13. $-,-\longrightarrow,-1975$. Studies on the freezing of green plantains. II. Sulfitation to control browning, J. Agric. Univ. P.R. 59 (2): 92-106.

14. - - - - - - 1975. Studies on the freezing of green plantains. III. Effect of stage of 
maturity at harvest on the quality of frozen products, J. Agri. Univ. P.R. 59 (2): 10714.

15.,,---1975 . Studies on the freezing of green plantains. IV. Effect of cold storage on the quality of frozen sliced green plantains, J. Agric. Univ. P.R. 59 (4): 239-44.

16. — and Parsi-Ros, O., 1977. Preparation and freezing of mashed taniers, J. Agric. Univ. P.R. 61 (4): 507-8.

17. — and Caloni, I. B., 1979. Frozen diced taniers, J. Agric. Univ. P.R. 63 (2): 268.

18. - and Hernández, I. 1977. Lye peeling of taniers (Xanthosoma spp.) J. Agric. Univ. P.R. 61 (3): $345-53$.

19. Sánchez-Nieva, F., 1977. Control of lye-peeled taniers, J. Agric. Univ. P.R. 61 (4): 489500.

20. Valldejuly-Aboy, C., 1962. Cocina Criolla, 6th ed, The Alpine Press, Inc. Boston, Mass. 